\section{Wątki masońskie w sztuce na dworze Stanisława Augusta}

AGNIESZKA SKRODZKA INSTYTUT HISTORII SZTUKI UKSW

W wieku XVIII, kiedy w Europie rozkwitło zainteresowanie masonerią, do lóż wstąpiło wielu przedstawicieli ówczesnych elit, w tym wybitnych mężów stanu, ludzi piór artystów i filozofów oraz członków niższych warstw spoleznych. Urokom ,sztuki królewskie"” nie oparli się także whadcy. Wiadono, zeje nie oparti sie takze whadcy Wiadomo, że masonem był np. Fryderyk I Wielki (1712-1786), kröl Prus, czy prezyden Stanów Zjednoczonych Jerzy Waszyngton (1732-1799). Wolnomularzem był najprawdopodobniej także polski monarcha, Stanisław August (1732-1798)'. Ta ostatnia informacja cały czas pobudza wyobraźnie zwłaszcza niektórych historyków sztuki, którzy na poparcie tej tezy wskazuja dzieła wykonywane na zamówienie tego władcy zawierające rzekomo masońskie przesłanie ${ }^{2}$.

1 L. Hass, Sekta farmazonii warszawskiej. Pierwsze stulecie wolnomularstwa w Warszawie (1721-1821),

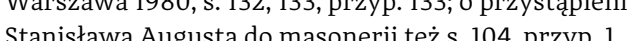

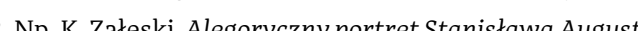
z, wlepsydra", Rocznik Muzeum Narodowego w Warszawie" 1977, nr 21, s. 237-249; A. Ryszkiewicz, Portrety Stanistawa Augusta, ,Wiek Oświecenia” 1979, nr 2, s. 96; K. Załęski, Polski portret wolnomularski,
Twierdzenia o wolnomularskich dziełach sztuki z kręgu Stanisława Augusta, jakkolwiek bardzo interesujące, nie zostały do tej pory przekonująco uargumentowane. Niniejszy artykuł ma na celu przedstawienie grupy tych obiektów i probę zakwestionow tacji ich prog programu ideowego.

Na temat związków Stanisława Augusta z wolnomularstwem wiemy dziś bardzo niewiele. Król milczy o tym w swoich pamiętnikach³. Jeśli chodzi o inne relacje

Stowarzyszenia Historyków Sztuki, red. A. Marczak-Krupa, Warszawa 1990, s. 213-214; K. Załęski, Stanislas Maler. Kunst am Hofe Stanislaus August Poniatowshis reg. 1764-1795, red. E. Charazińska, München 1995, [bns.], nr kat. 11; J. Polaczek, Upadek I Rzeczypospolitej w malarstwie igrafice europejskiej przetomu XVIIII XIX wieku, ,Res Historica. Od rozbiorów Rzeczypospolitej

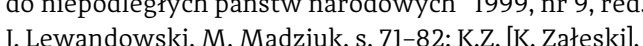
Portret Stanistawa Augusta z klepsydra, 17993, w: Stanisław August, ostatni król Polski. Polityk, mecenas, reformator, 1764-1795 [katalog wystawy], red. A. Soltys, Warszawa 201, s. 468-469.

Zob. Stanislas Auguste, Mémoires du roi Stanislas-Auguste Poniatowski, wyd. S.M. Goriänov, t. t, St.-Péterspamiętników ukazało się kilka lat temu: Stanislas Auguste, Mémoires, wyd. A. Grześkowiak-Krwawicz, D. Triaire, Paris 2012 (Collection historique de l'Institut d'études slaves. - LXVIII); w języku polskim pamiętnik

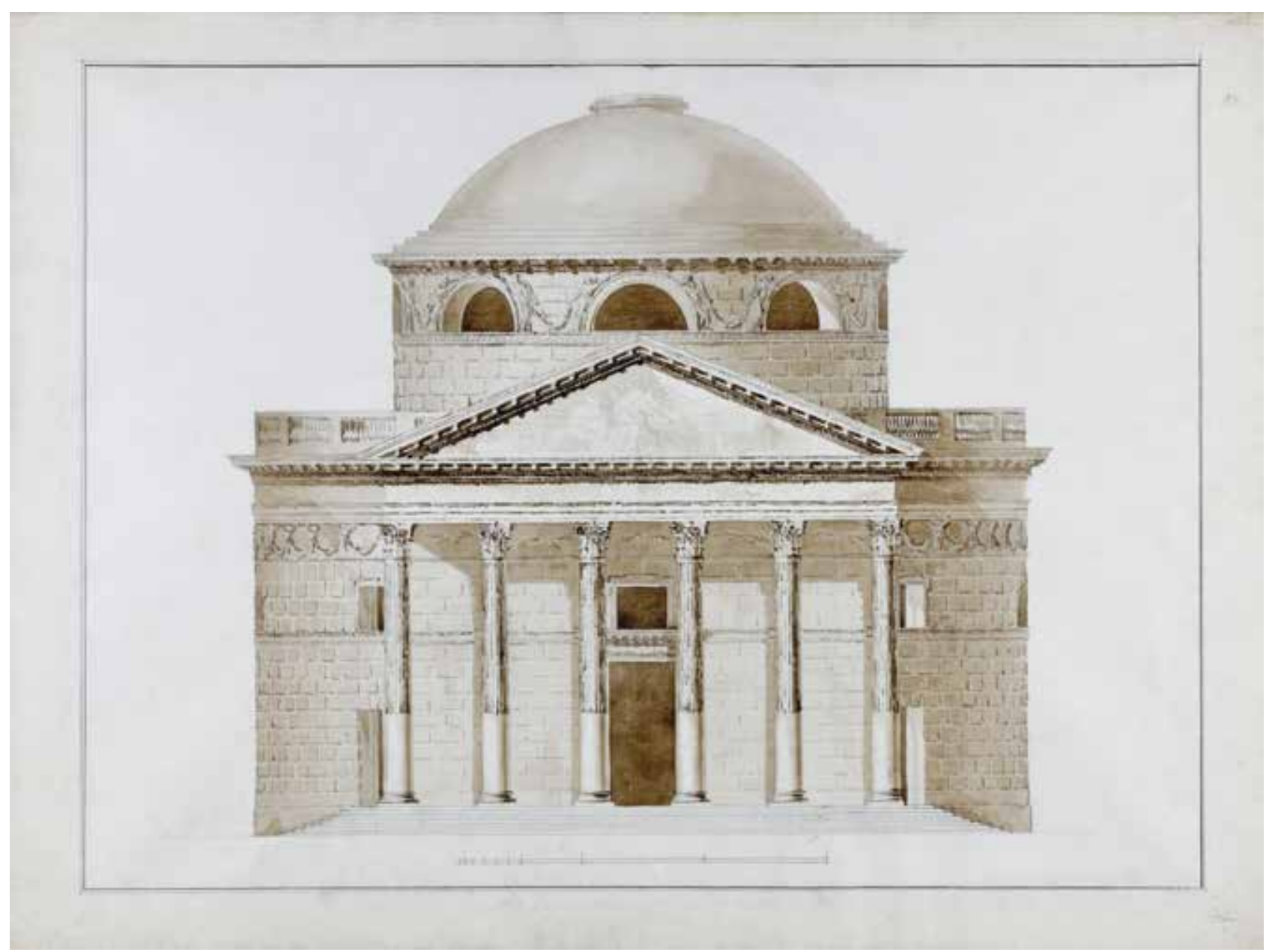

1. Jakub Kubicki, Projekt kościoła Najwyższej Opatrzności. Elewacja frontowa budowli na planie koła zopułą na bębnie i zzzesciokolumnowym portykiem, 1785-1786. W tympanonle symbol Opatrznos

w Warszawie, nr inw. Inw.zb.d. 8623. Fot. Pracownia Reprograficzna BUW

z epoki, warto w pierwszej kolejności zwrócić uwage na fragment wspomnień barona

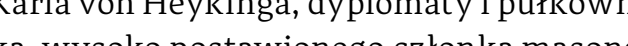
ka, wysoko postawionegoczlonka masone rii, przebywającego w Warszawie przez cały okres panowania Stanislawa Augusta (z przerwami)4. Heyking zajmował się przyjmowaniem adeptów do stołecznej loży i wtajemniczaniem ich do kolejnych stopni. W 1777 r. pisał on, że kręgi warszawskiej

fragmentach: Pamiętniki króla Stanisława Augusta. fragmentach: Pamiętniki krola Stanistawa Augusta.
Antologia, wybór tekstu D. Triaire, tum. W. Brzozowski, wstęp A. Grześkowiak-Krwawicz, red. M. Dębowski, Warszawa 2013.

4 W. Zawadzki, Wstęp, w: Polska stanistawowska w oczach cudzoziemców, t. 1, oprac. i wstęp W. Zawadzki, Warszawa 1963 (Biblioteka Pamiętników Polskic farmazonii rozrosły się tak bardzo, iż wzbudziło to zazdrość polskiego króla, który od dawna bezskutecznie zabiegał o uznanie społeczeństwa ${ }^{5}$. Za zgodą monarchy wstapił wówczas do loży sekretarz

Stanisława Augusta, Maurycy Glaire. Jego ukrytym celem było przyjrzenie się na polecenie króla działalności w kregach wolnomularskich Ignacego Potockiego, wówczas nego o chęć utworzenia wśród „braci” tajnego stronnictwa, nieprzychylnego monarsze $^{6}$. Niewyk

5 K.H. Heyking, Wspomnienia z ostatnich lat Polski i Kurlandii 1752-1796, tłum. W. Zawadzki, w: Polska

6 Tamże, s. 137 pisarza wielkiego litewskiego, podejrzewa- 

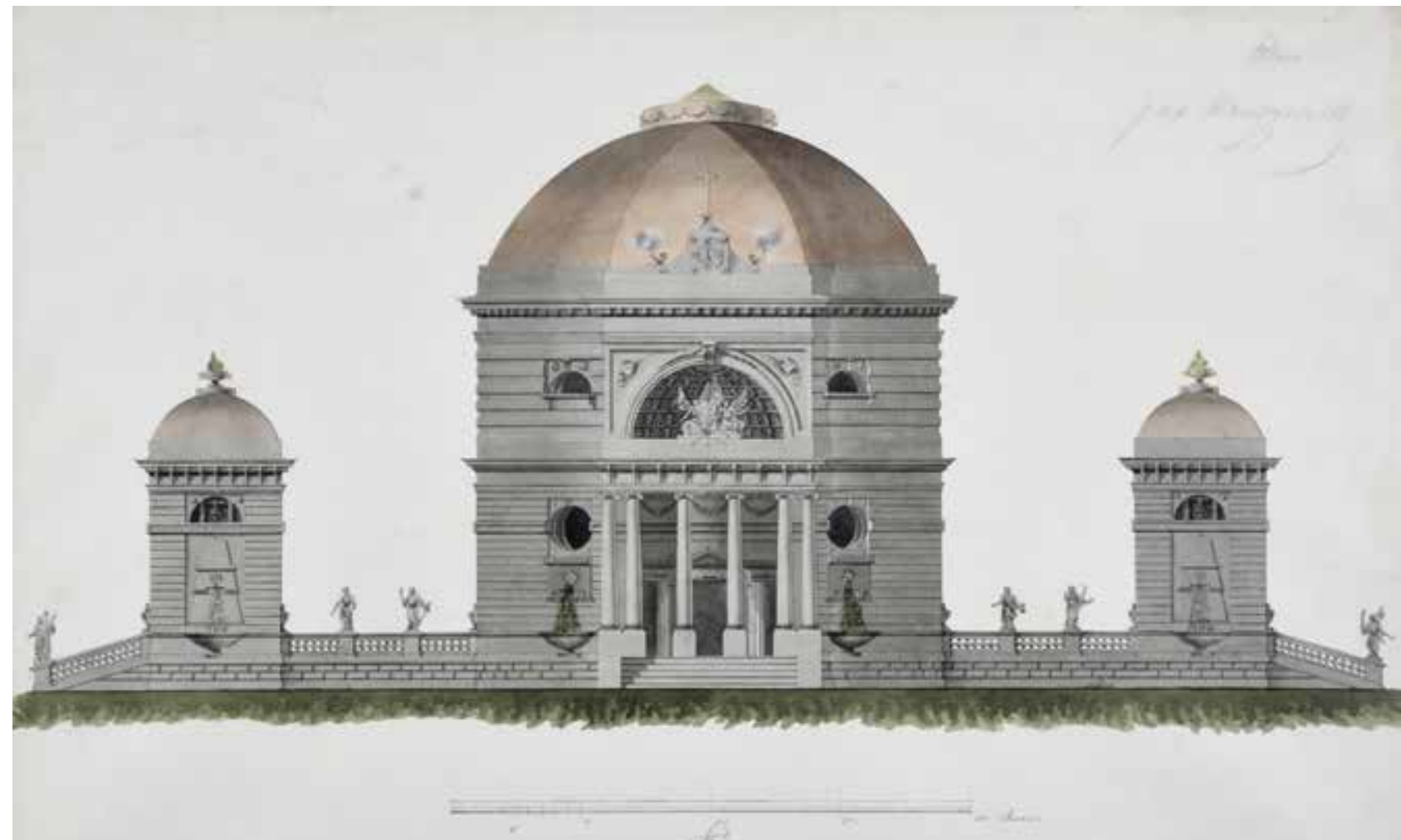

2. Feliks Kruszewski, Projekt kościoła Najwyższej Opatrzności. Elewacja frontowa, 1791-1792. Gabinet Rycin Biblioteki

Uniwersyteckiej w Warszawie, nr inw. Inw.zb.d. 8532. Fot. Pracownia Reprograficzna BUW

wszystkim właśnie rosnąca popularność warszawskiej organizacji wolnomularskiej przyczyniła się do decyzji monarchy, żeby włączyć się w kreggi jej sympatyków. Być może władca sądził, że jego członkostwo zapobiegnie powstawaniu tam frakcji mu przeciwnych, lub przynajmniej ograniczy tę tendencję, i przysporzy mu zwolenników. Nie dowiemy się jednak z relacji Heykinga niczego na temat przynależności Stanisława Augusta do masonerii, choć baron z pewnością był jedną z najlepiej zorientowanych wówczas osób.

Nieco więcej informacji o tej sprawie zawieraja XIX-wieczne op acowania historiograficzne. Walerian Kalinka wspomnia że król wstapił w 1777 r. do loży niemieckie Rose Croix [Różokrzyż] oraz złożył przysie-gę „warunkową wprawdzie co do wypełniania obowiązków lecz bezwarunkową co do zachowania tajemnicy"7. Nie wiadomo jednak, czego owa tajemnica miała dotyczyć jeśli bowiem chodzi o przynależność, niektórzy członkowie oficjalnie się do niej przyznawali. Świadczy o tym przywołany przez Jędrzeja Kitowicza przykład wojewody mazowieckiego Andrzeja Mokronowskiego, jednego z pierwszych warszawskich farmazonów, założyciela loży Trzech Braci.

7 W. Kalinka, Ostatnie lata panowania Stanistawa Augusta, Poznań 1868, s. LXI, przyp. 1. 8 Zob. rozdział O wiarach jakie były w Polszcze za

wydaniach Opisu obyczajów za panowania Augusta III

J. Kitowicza, a wydrukowany w: „Pamiętniku Literackim" 1930, r. 27, s. 130. Kitowicz wspomina, że mason "przymioty osob, jak też powinnosci konfraterni
chowają pod wielkim sekretem" (s. 130) O Mokronowskim jako wolnomularzu: S. Małachowski-Łempicki, Wykaz polskich lóż wolnomularskich oraz ich członków w latach 1738-1821 poprzedzony zarysem. historii wolnomularstwa polskiego i ustroju Wielkiego

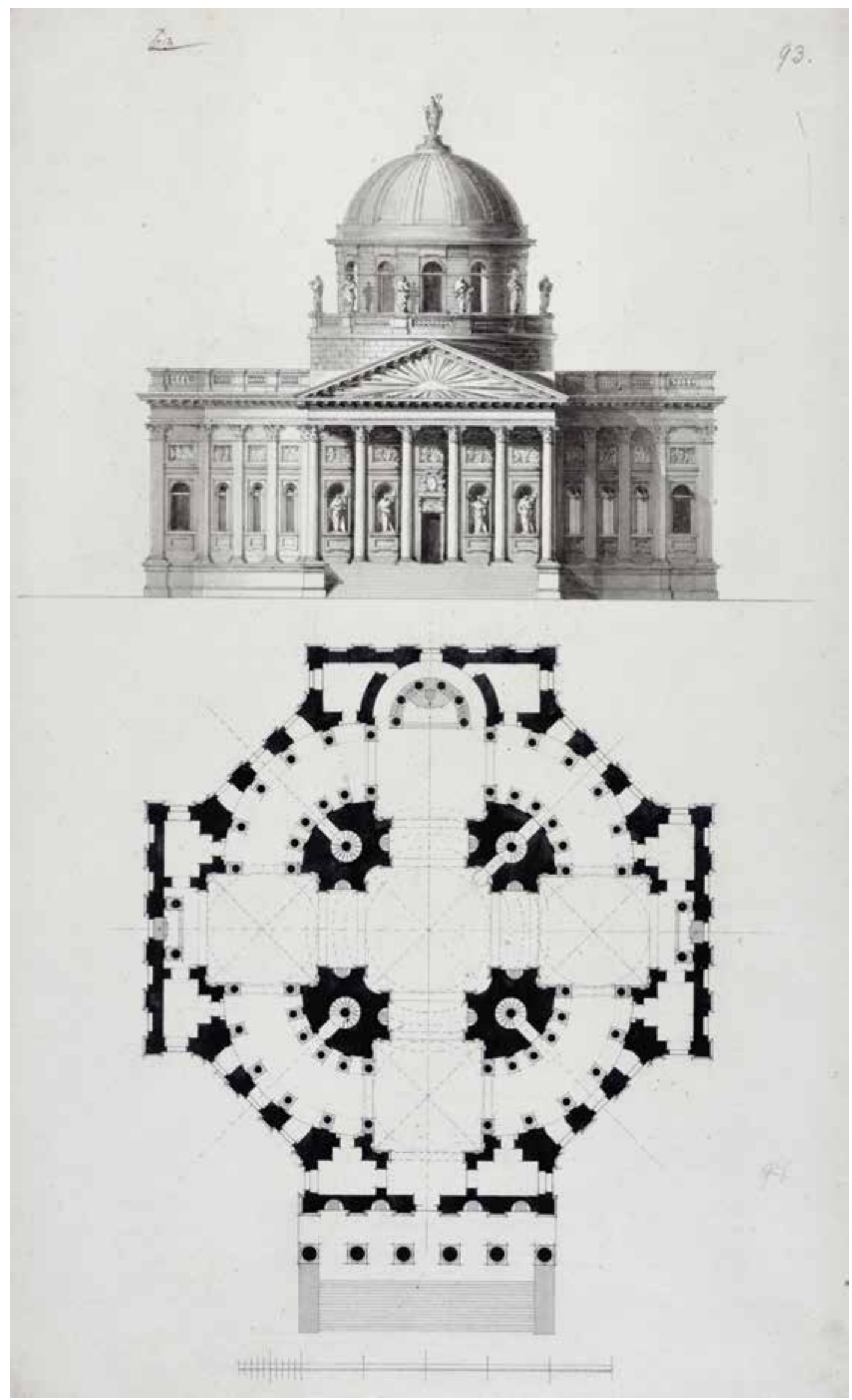

Rzutielewacja

frontowazed

proponowanych

wariantów ko-

puły, 1791-1792

nie symbol

Boskiego Oka

w trójkącie

w promienistej

glorii. Gabinet

Uniwersytec-

kiej w Warsza-

wie, nr inw.

Inw.zb.d. 8121.

Fot. Pracownia BUW 
Król, wstępując do Rose Croix, przyjął imię masońskie Salsinatus. Ten anagram łacińskiego Stanislaus oznacza „urodzony z posolonego"9 , sól zaś - według symboliki biblijnej - to mądrość ${ }^{10}$. Jest ona również ważnym elementem alegorii związanych z masonerią (więcej na ten temat niżej)"1, a jej sens częściowo pokrywa się z biblijnym. Oznacza m.in. wiedzę oraz nauczanie, które są celem lóż wolnomularskich ${ }^{22}$. Imię

9 Choć fakt utworzenia masońskiego imienia króla z łacińnkkiego Stanislaus znany jest w literaturze i czesto pojawia sie w niniejszym artykule po raz pierwszy. Za pomoc w przekładzie dzięluję dr Małgorzacie Jesiotr. 10 Biblijna interpretacja soli jako mądrości należy do najbardziej rozpowszechnionych dzięki skierowany do apostołów słowom Chrystusa zawartym w ewangeliach Mateusza, Marka i tukasza (Mt 5, 13; Mk 9, Zk 14, 34-35). Najbardziej znany jest fragment Mateusza: „Wy jesteście solą ziemi. Lecz jeśli sól
utraci swój jmak, czymże jạ posolić?” (Mt 5, 13). Sól w Piśsmie Świętym ma także inne znaczenia. Jest symbolem kary, przymierza z Bogiem, oczyszczenia i trwałoości. XLD [X. Leon-Dufour], Sól, s.v.v, w: Stownik teologii biblijnej, red. tenże, tłum. i oprac. K. Romani temat symboliki soli w Biblii, a także u untorón

starożytnych i w kulturze ludowej zamieściła D. Forstner, Świat symboliki chrześcijańskiej. Leksykon ttum. i oprac. W. Zakrzewska, P. Pachciarek, R. TuZyński, koment. do ilustracji $M$. Wizesniak, soli, rozpowszechnionych w literaturze antycznej i pismach Ojców Kościoła, przedstawił Philippo Picinelli. Wśród nich są następujące: człowiek niecierpliwy, niewdzięcznik, fałszywy przyjaciel, prała, pilnoscc, umiar kowana łagodnosc, umiarkowaMundus symbolicus in emblema tum univer Pictine formatus, explicatus, et tam sacris, quàm profanis eruditionibus ac sententiis illustratus: subministrans oratoribus, praedicatoribus, academicis, poetis \&c. innumera conceptuum argu

Agrippinae 1687, s.70-72. 11 P. Naudon, Histoire générale de la Franc-Maçonnerie, anjeleka z alesorycznym przedstawieniem masonów przy pracy za którymi znaiduje sie kolumna z symbolam alchemicznymi: ognia, powietrza, wody i soli.

12 G. Oliver, A dictionary of symbolical masonry includin The Royal Arch Degree; according to the system prescribed by the Grand Lodge and Supreme Grand
Salsinatus doskonale zatem odpowiadało nie tylko duchowi epoki, ale także aspira-

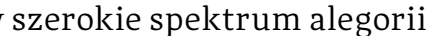
i symboli masońskich.

Kalinka twierdził, że znany jest mu list monarchy z 1780 r., w którym władca pisze w języku niemieckim o płaconych przez siebie składkach na cele wolnomularstwa. Historyk zaznaczył jednak, że nie są mu znane żadne inne, późniejsze dokumenty dotyczące uczestnictwa króla w tym ruchu'13. Warto zwrócić uwage na to stwierdzenie Kalinka który specializowat się w czasch stanistawowsich" nie ni wię na zrodtazokresu po 1780 r. Swatknął się nazróda zokrespo 1780 r. świadczące o działalności władcy w masoneril. Wydaje się, że nie powinniśmy tego faktu ignorować, szukając interpretacji wolnomularskich w dziełach sztuki powstałych na zamówienie Stanisława Augusta.

Kilka lat temu Tadeusz Cegielski podał, że Walerian Kalinka oparł się w powyższych ustaleniach na informacjach Hipolita Skimborowicza, kustosza Muzeum Staróytnosiuniwersytetu Warazeum Staraytnosiuniwersytetu Warszawskiego itworcy „styn Nie walej masoników '. Nie wiadomo jednak, skąd Cegielski czerpał tę wiedzę, skoro Kalinka nie zamieścił w swojej pracy odnośnego przypisu ani nie zawarł w niej bibliografi. Natomiast źródło, z którego korzystał Skimborowicz, nie dotrwało do naszych czasów, jak pisze Cegielski ${ }^{16}$

\section{authorities, London 1853, s. 318-319. Inne przytoczone} ciągłość, trwałość́.

13 W. Kalinka, dz. cyt., s. LXI, przyp. 1.

W. Kan

lata panowania Stanistawa Augusta, warto Ostatnie jego Sejm czteroletni, t. I-3, Kraków 1895-1896, czy pracę Konstytucja trzeciego maja, Kraków 1896.

15 T. Cegielski, Domek Biały i hermetyczno-alchemiczn

zainteresowania Stanistawa Augusta, w: Łazienki Królewskie. Nowe świadectwa - nowe znaczenia, re 6 . Tamże, s. 64, przyp.10.

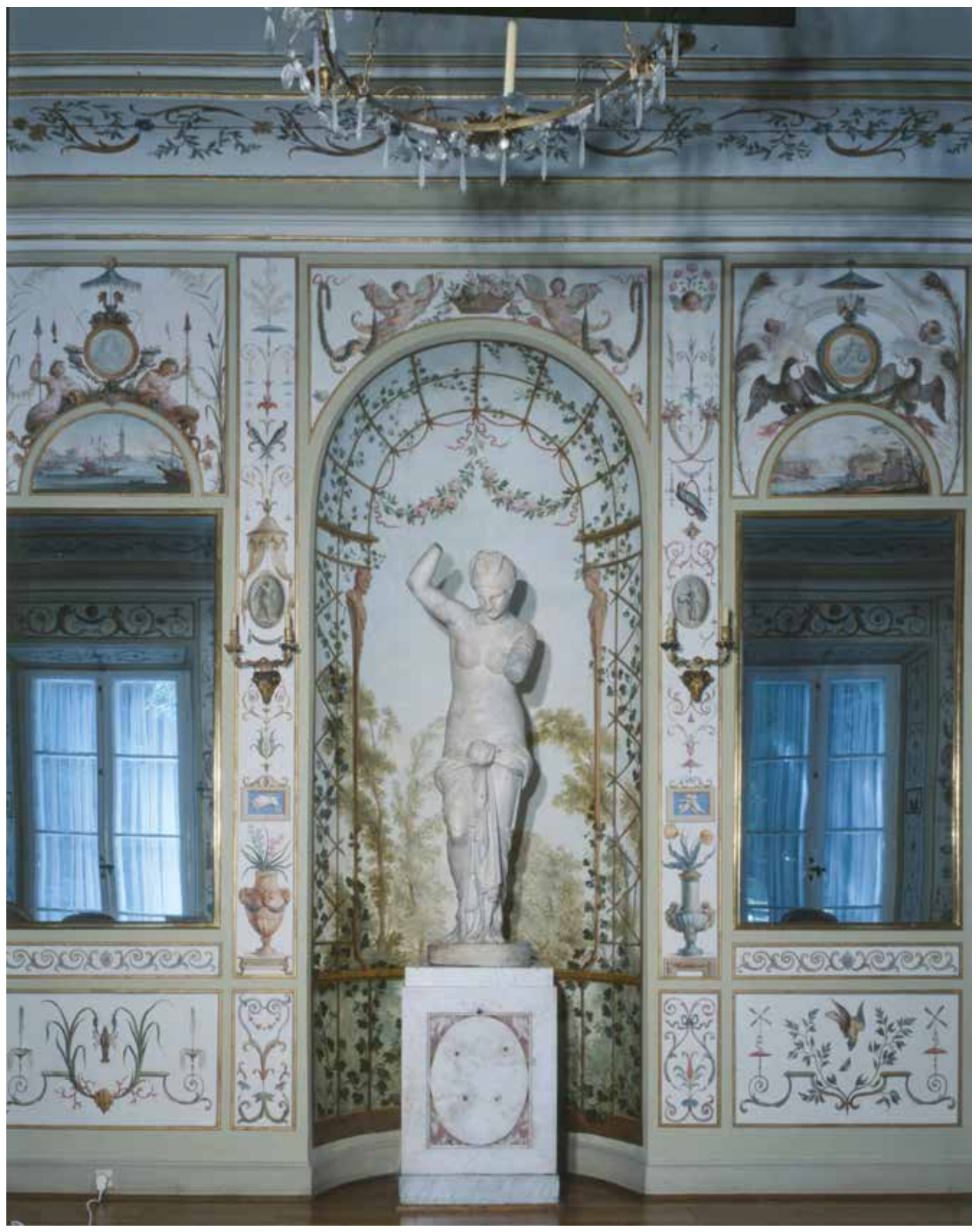

4. Sala Stołowa Białego Domu ze statuą Wenus Anadyomene w niszy. Malowidła ścienne: Jan Bogumił Plersch, ok. 1777 r. Posąg Wenus: rzymska replika typu hellenistycznego posągu Afrodyty Anadyomene, pocz. II w., uzupełnienia: André Le Brun, przed 1777 r. Biały Dom: proj. Domenico Merlini, 1774-1776. Fot. P. Jams 


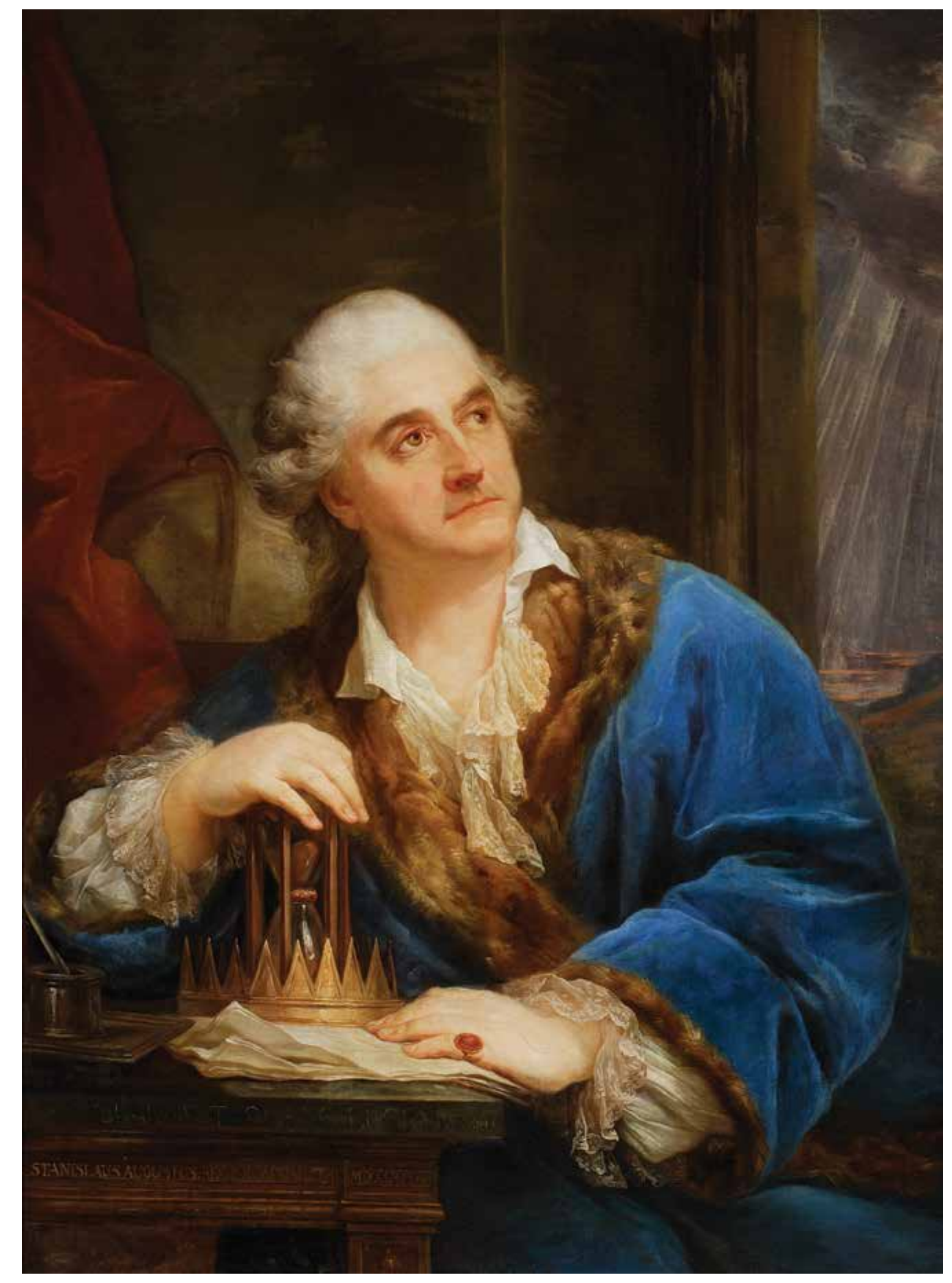

Z kolei Kazimierz Marian Morawski odnotował, że Stanisław August miał zetknać się z wolnomularstwem jeszcze jako młodzieniec, przed wstapieniem na trako w 1753 lub 1754 r., w czasie swoj drugiej w 1753 lub i754r., wczasie swojej drugiej podróży po Europie ${ }^{17}$. Według Morawskieg monarcha w 1779 r. został przyjęty za pośrednictwem Maurycego Glaire’a jako „kawaler różano-złocistego krzyża" do loży Karol pod Trzema Hełmami, mieszczącej s w domu gminy ewangelickiej przy ulicy Królewskiej w Warszawie ${ }^{18}$. Monarcha mia złożyć przysięge „z zastrzeżeniem swych obowiązków obywatelskich i królewskich", obó jęz imię mań Magn Magnus. Morawski, powołując się na ni wskazaną w przypisach pracę Szymona Askenazego, podkreślał dwukrotnie, że „król »w zakonie« czuł się niedobrze”. Także ten badacz nie podał żadnych dowodów na zaangażowanie się władcy w prace masonerii sugerując, że udział monarchy ograniczył się jedynie do „figurowania na liście członków czcigodnego bractwa Różo-Krzyża"

Kolejny autor, historyk i wybitny polski znawca masonerii Ludwik Hass, w monografii Sekta farmazonii warszawskiej przywołał wspomniane przez Kalinkę fakty wstąpienia Stanisława Augusta do organizacji i uiszczania opłat. Według Hassa król podobno przyjął w loży imię Salsinatus eques a corona vindicata ${ }^{21}$, co można tłumaczyć

jako „Urodzony z posolonego kawaler korony chronionej"22. Imię to, jak sądze naw zywało do wiary Stanisława Augusta

17 K.M. Morawski, Źródło rozbioru Polski. Studia i szkice zery Sasów istanistawów, Warszawa 1935, s. 236 .

18 Tamże, s. 236.

19 Tamże, s. 240-24l.

20 Por. tamże, s. 241.

21 L. Hass, dz. cyt., s. 104, 107, 115, 130

22 Słowo vindicata można jednak tłumaczyć wielorako: „oswobodzona", , ,odzyskana", ,pomszczona”, , ,do której ktoś rości sobie prawa". Za pomoc w tłumacze- w sprawowaną nad nim szczególną opiekę Opatrzności. Notabene, imię Eques a corona vindicata nosił także w kregach masońskich nny nieszczęśliwy" monarcha ${ }^{23}$, szwedzki tadca Gustaw III, zamordowany na balu maskowym w $1792 \mathrm{r}^{24}$

Najnowsze badania nie poszerzaja stanu wiedzy na dyskutowany tu temat. Historyk Tadeusz Cegielski podkreślił ostatnio, że nie dysponujemy obecnie żadnym dowodem źródłowym na członkostwo Stanisława Augusta w masonerii ${ }^{25}$. Profesor Cegielski, w latach 2000-2003 wielki mistrz Wielkiej Loży Narodowej Polskie, niedawno

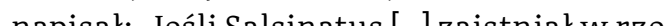
czywistóci, to ba dziejjako byt paperowy,

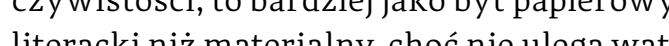

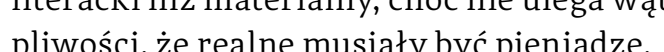
piw zosi, ze meane musialy byc pieniądze, kwota siedemdziesiąt sześć i pół dukata [...], którą król musiał zapłacić za swoją inicjację W zachowanej w Bibliotece Czartoryskich masońsko-hermetycznej korespondencji Augusta Moszyńskiego z królem brak jakiegokolwiek śladu wskazującego na przynależność Stanisława Augusta do wolnomularstwa" ${ }^{27}$

Zatem informacje o członkostwie króla, które pojawiały się w opracowaniach historycznych, obecnie trudno zweryfikować. Te źródła, z którymi badacze mieli do czynienia, były nieliczne i lakoniczne oraz dotyczyły tylko lat 1777-1780. A przede wszystkim nie wskazywały na zainteresowanie króla kwestiami wolnomularstwa.

Jednymi z obiektów wiązanych ze sprawami masońskimi są projekty

23 Na temat „królów nieszczessliwych" zob. A. Skrodzka, Udręki majestatu. Polscy „krolowie nieszczęśliwi w ikonografi nowożytnej, Warszawa 2018. 24 Verzeichniss sämmtlicher innern Ordensbrüder der strikten Observanz, druk. B. Berndt, Leipzig 1847 ,

25 T. Cegielski, dz. cyt., s. 64-65.

26 Zob. Tadeusz Jan Cegielski https://pl.wikipedia.org/

wiki/Tadeusz_Cegielski [dostę 
6. Plafon Sali Salomona w pałacu Na Wodzie, stan z 1922 r. z obrazami Marcella Bacciarellego: w owalu Sen króla Salomona, pod nim w fasetach: Narada z krolem Hiramem iobol
(obecnie zaginione), 1788-1793. Fot. J. Jaworski, ze zbiorów Towarzystwa Opieki nad Zabytkami Przeszłości, obecny nr inw. IS_PAN_BRoooooo6883

świątyni Opatrzności, które pojawiły się już w 1775 r., a które rysowano także w latach 1781-82 i 1784-86 i późniejej (il. 1-3). Uchwalenie Konstytucji з maja zakończyło poszukiwanie formy idealnej dla tego ważnego sanktuarium. Wybrano projekt Jakuba Kubickiego powstały w 1792 r Zapropowa Zaproponowat on montą, pełn rozmachu centralną budowlę na planie ośmioboku składającego się z krzyża greckiego i wpisanego weń koła 29. Świątynia miała stanowić przede wszystkim pamiątkę przyjęcia Konstytucji i jednocześnie stanowić ex voto za jej uchwalenie. Zdecydowano, że kościół zostanie poświęcony Najwyższej Opatrzności, „na podziękowanie Bogu [podkr. A.S.] za zdarzoną chwile pomyślną wydobycia Polski spod przemocy rządu, który najskuteczniej wolność naszą prawdziwą i całość Polski zabezpieczyć może, za postawienie tym sposobem ojczyzny naszej na stopniu mogącym prawdziw w oczach Europy zyskać jej konsyderację [t]. szacunek]"30.

Jak wiadomo, sanktuarium nigdy nie zostało wzniesione w kształcie zaaprobow

28 K. Karaskiewicz, Stanisław Kostka Potocki- pomystodawca i kontynuator marzenia królewskiego? Czyli krótka historia budowy pewnego kościoła, ,Studia Wilanowskie" 2010, nr 17, s. 104. Zob. o projektach: . Wątroba, Warszawskie obchody pierwszej rocznic Opatrzności w w Ujazdowie, w: Stanistaw August ostatni..., dz. cyt., s. 444-449 oraz: tenże [jako P.W. Rzut sytuacyjny kościoła Najwyższej Opatrzności, 1792, w: tamże, s. 457-458, nr 240. 29 M. Kwiatkowski, Stanistaw August. Król - Architekt, Wroctaw 1983, s. 229-230; P. Wątroba, Rzut..., dz. cy 5. 457-459. Ostatnio: J. Kowalczyk, Architektura, wicz, J. Kowalczyk, E. Łomnicka-Żakowska, Z. Michalczyk, J. Sito, Sztuka polska. Późny barok, rokoko, klasycyzm (XVIII wiek), Warszawa 2016, s. 89 . 30 Deklaracja stanów zgromadzonych (CCLXXVIII), w: Volumina Legum, t. IX, druk Wł.L. Anczyc i Spótka,

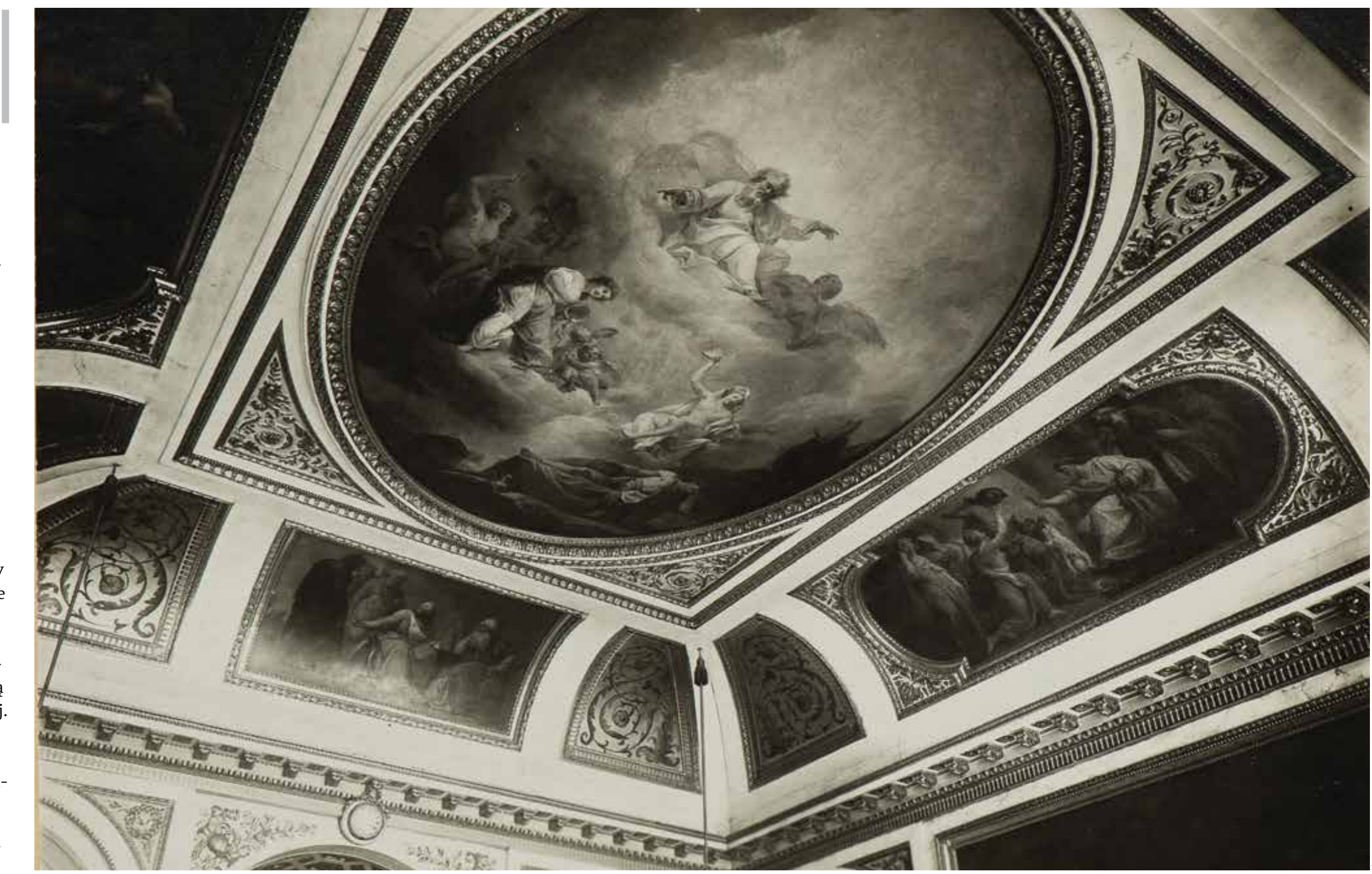

nym przez Stanisława Augusta. 3 maja 1792 r., w trakcie obchodów rocznicy uchwalenia Konstytucji ${ }^{11}$, miała jednak miejsce uroczystość wmurowania kamienia węielnego z udziatem króla, prymasa Michala Poniaztuskiego ilicznych podda nych. Doke znana jest $\mathrm{z}$ „,Korrespondenta 31 D. Nawrot, Obchody pierwszej rocznicy Konstytucji
3 Maja w Warszawie, „Niepodległość i Pamięc" 2000, nr 16, s. 67-75.
Warszawskiego" ${ }^{\prime 32}$. Uroczystość odbyła się według wskazówek zawartych w Rituale Romanum ${ }^{33}$. Po solenn Świętego Krzyża, połączonej z sesją parla-

32 [B.a.], Wstęp do Opisania Dnia 3. Maia, „Korrespon(n) dent Warszawski Donoszący Wiadomos,

33 Ritus benedicendiet imponendi primarium lapidem pro Ecclesia aedificanda servandus a Sacerdote facultatem habente ab episcopo, w: Rituale Roman Pauli V pontificis maximi iussu editum, Roma mentu, władca udał się procesyjnie na plac Ujazdowski. Tam prymas poświęcił (egzorcyzmował) sól i wodę. Chociaż „Korrespondent” o tym nie wspomina, celebrans zapewne połączył te dwa składniki zgodnie z nakazem rytu, na wzór proroka Elizeusza, który oczyścił źródło, wrzuciwszy do niego sól. miejsce na ołtarz, gdzie położno kamień, i wypowiedział modlitwę z nałożeniem na kamień ręki oraz poświęcił go wodą. Potem, począwszy od króla, rzucano wapno oraz Następnie prymas pokropił posoloną wodą 
wzniesiono nad kamieniem oktogon, a następnie sześcian zwieńczony krzyżem³.

Zwolennikom wolnomularskich in-

terpretacji stanisławowskich dzieł sztuki już sam fakt budowania sanktuarium kojarzył się z masońskim rytem wznoszenia świątyni Salomona i związaną z tym symboliką dotyczącą duchowej budowy salomonowego gmachu przez „braci” ${ }^{35}$. Biblijny władca Izraela oraz budowniczy świątyni jerozolimskiej Hiram Abif to wszak kluczowe postaci w mitologii i rytualistyce wolnomularskiej. Poza tym poświęcenie kamienia wegielnego mogho nasuwać myś mienia wegies poza týn o masonskim zwyczaju posypy wania solą undamentów nowo wznoszonej loży. Sól ewokowała wówczas przyjaźn i wiernośćc ${ }^{30}$ nawiązując zapewne do Księgi Kapłańskiej (Kpł 2,13), gdzie opisano użycie soli w trakcie zawierania przymierza z Bogiem. Skojarzenia te wydają się jednak niewystarczające do uzasadnienia wolnomularskich interpretacji związanych z sanktuarium Opatrzności. Nie przekonuje także twierdzenie Katarzyny Karaskiewicz, twick ze kościol ujazdow ki to pom Sophii (Mądrości Przedwieczne)). Dowodz tego ma brak w Ustawie Rzadowej z 1791 r. zapisu, że kossciół Najwyższej Opatrzności ma być kościołem katolickim, a także fakt, że jego budowniczowie byli masonami ${ }^{37}$. Zdanie to podzielał Paweł Borecki, zresztą również na łamach wolnomularskiego czasopisma „Ars Regia" ${ }^{38}$. Hipotezy te

\section{4 [B.a.], Wstęp..., dz. cyt., s. 12-13.}

35 Sugestie te pojawity się chociażby w katalogu T. Cegielski, Muzeum Narodowe w Warszawe, Warszawa 2014, s. 85.

36 C.F.W.Dyer Symbolism in Craft Freemasonry London 1986, s. 59.

37 K. Karaskiewicz, Budowniczowie pierwszego kościoła Najwyższej Opattzności - wolnomularze, ,Ars Regia. Czasopismo poświęcone myśli i historii wolnomula stwa" 2010, nr 12/19, s. 52

38 P. Borecki,Historia pewnej świątyni- historiq̨ należy odrzucić w świetle badań przeprowadzonych przez Urszulę Grochowską. tów architektury sakralnej Jakuba

Kubickiego, nie odnajdujc żadnego sladu

Kubickiego, nie odnajdując żadnego ślad u . rium ujazdowskiego $0^{3}$

Badacze doszukują się wolnomularskich znaczeń również w przypadku dekoracji Sali Stołowej Białego Domu

w Łazienkach (il. 4). Biały Dom, popularnie zwany obecnie Białym Domkiem, a w źródłach określany jako La Maison Blanche, został wybudowany w latach 1774-1776

Pomyślano go jako willę typu mason. Pomyślano go jako willę typu maison de plaise. We wnętrzu tej budowli, w Sali tołowej (Jadalnej) znajdują się oryginalne scienne dekoracje groteskowe namalowane przez Jana Bogumiła Plerscha ok. 1777 r. Centralnym miejscem w pokoju jest nisza, w którą wstawiono statuę zwaną w źródłach Venus, Venus de Medicis lub Wenera, faktycznie należącą do grupy rzymskich replik, powtarzajacych typ hellenistyczeo pon go posaco Afrodyty Anadyomene, czyli "Wychodzącej z wody". Wenus z Białego Domu to rzeźba z początku II w., zakupiona dla Stanisława Augusta w Rzymie przez królewskiego rzeźbiarza André Le Bruna, uzupełniona przez niego i ustawiona w niszy Jadalni w 1777 r., na tle malowidła ściennego wyobrażającego ogrodową altanę ${ }^{40}$. Witold Dobrowolski podał ostatnio, że chometkań wolnomularzy,

myśli i historii wolnomularstwa" 2010, nr 12/19,
s. 39-49.
39 U. Grochowska, Architektura sakralna Jakuba
Kubickiego, Warszawa 1989, praca magisterska
napisana na Wydziale Kościelnych Nauk Historycz-
nych i Społecznych w Akademii Teologii Katolickiej
pod kierunkiem dra hab. Zbigniewa Bani, ss. 79.
40 K. Mikocka-Rachubowa, André Le Brun, ,pierwszy
rzeébiarz" króla Stanistawa Augusta, t. 2, Warszawa
2010, s. 51 .

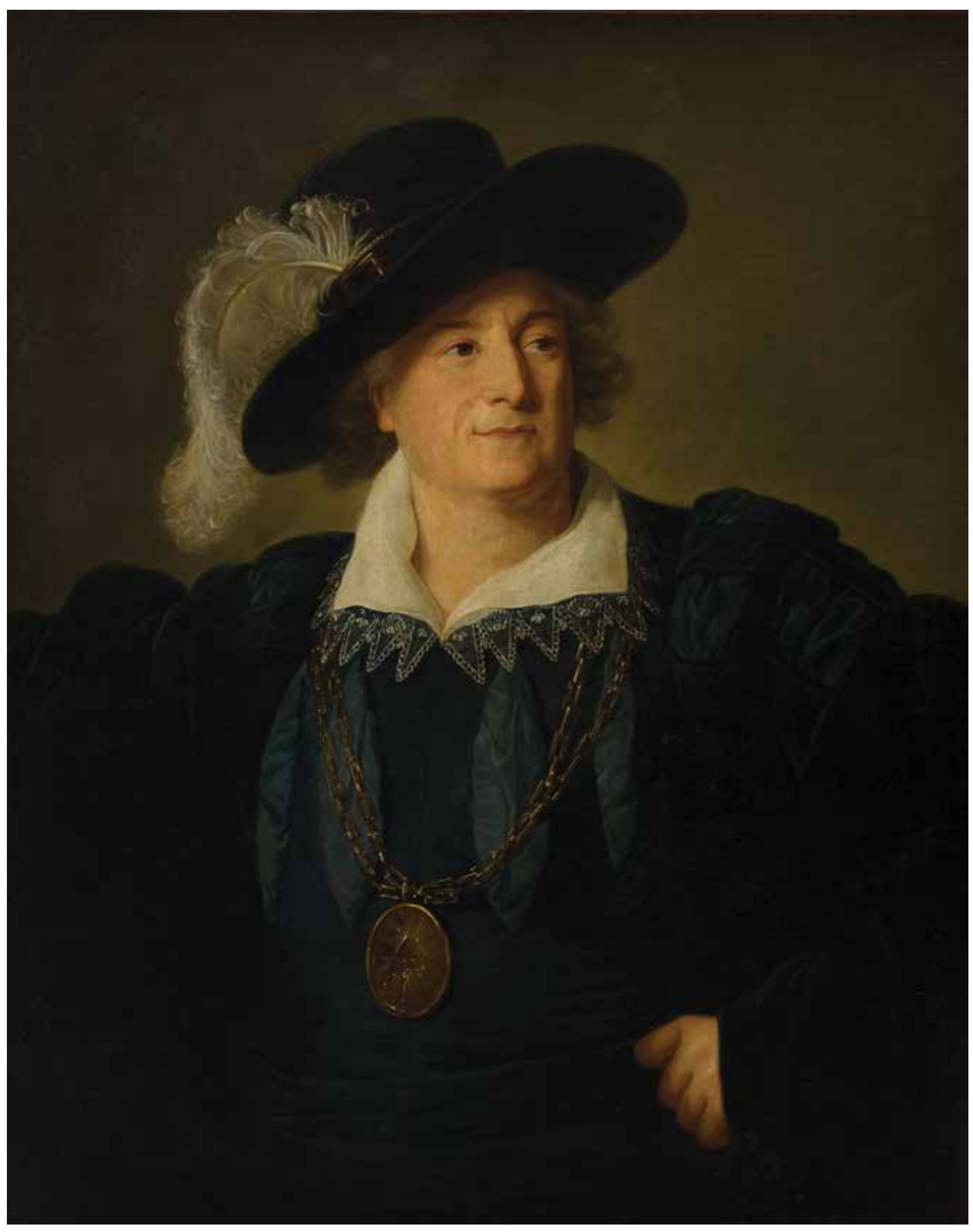

7. Kopia wg Elisabeth Louise Vigée-Lebrun, Portret Stanisława Augusta w stroju à la Henryk IV, po 1797 r., w zbiorach Muzeum Narodowego w Krakowie, nr inw. MNK XII-a-155. Fot. Pracownia Fotograficzna MN 
posąg zaś był rzekomo wówczas uznawany za Izis - egipską boginię natury, pełniącą ważną rolę w rytach masońskich. Weachą Dobrowolskiego posąg ów jest zatem "Wenus-Izydą"41.

Trudno się zgodzić z taką interpretacją. Przede wszystkim słowniki masoński nie potwierdzają utożsamiania przez wolnomularzy Wenus z Izydą. Brakuje w tych kompendiach jakichkolwiek wskazówek, które pozwalałyby wnioskować, że w rytach masońskich nie tylko w drugiej połowie XVIII w., ale w ogóle kiedykolwiek Izyda mogła być postrzegana jako Wenus ${ }^{42}$ Co więcej, leksyky wolno jo Wre ${ }^{4}$ Co więcej, leksykony wl nularskie wyraźnie odrozniają oble boginie, uznając je za greckim historykiem Diodorem Sycylijskin za dwie siostry, córki Jupitera i Junony. Przy czym Izyda jest konsekwentnie uznawana za patronkę natury, Wenus zaś - miłości ${ }^{43}$. Zestawienia Wenus z Izis nie potwierdz także choćby odnośne hasło w Wielkiej Encyklopedii Francuskiej Diderota ${ }^{44}$. Poza tym znane dziś źródła dotyczące Białego Domu, które wspominają posag „wychodzạcej z wody", nigdy nie mówią o niej jako o Izis45.

41 W. Dobrowolski, Treści masońskie w dekoracji Sali Jadalnej w Białym Domu w Eazienkach, w: Eazienki Królewskie.., dz. cyt., s. 53 .

42 Isis, s.v., w: A.G. Mackey, An encyclopaedia of freemasonry and its kindred sciences: comprising the whole range of arts, sciences and literature as
connected with the institution, Philadelphis 1884,

371, gdzie Isis jest nazwana wielka boginia natury". W cytowanym wyżej słowniku Olivera brakuje hasła poświęconego Izydzie. Zob. G. Oliver, dz. cyt.

43 R. Macoy, General history, cyclopedia and dictionary of freemasonry, containing an elaborate account of the rise and progress of freemasonry and its kindr associations - ancient and modern, also definitions 1870, s. 175 .

44 Zob. Isis, s.v., w: D. Diderot, J. Le Rond D'Alembert, Encyclopédie, ou Dictionnaire raisonnédes sciences, des arts et des métiers, vol. 8, Paris 1766, s. 913-915.

45 Źródła, z wypisami w oryginale, podaje Katarzyna Mikocka-Rachubowa. Są wśród nich Rapport généra des Fabriques z 1777 r.; inwentarz z 1783 r., takze

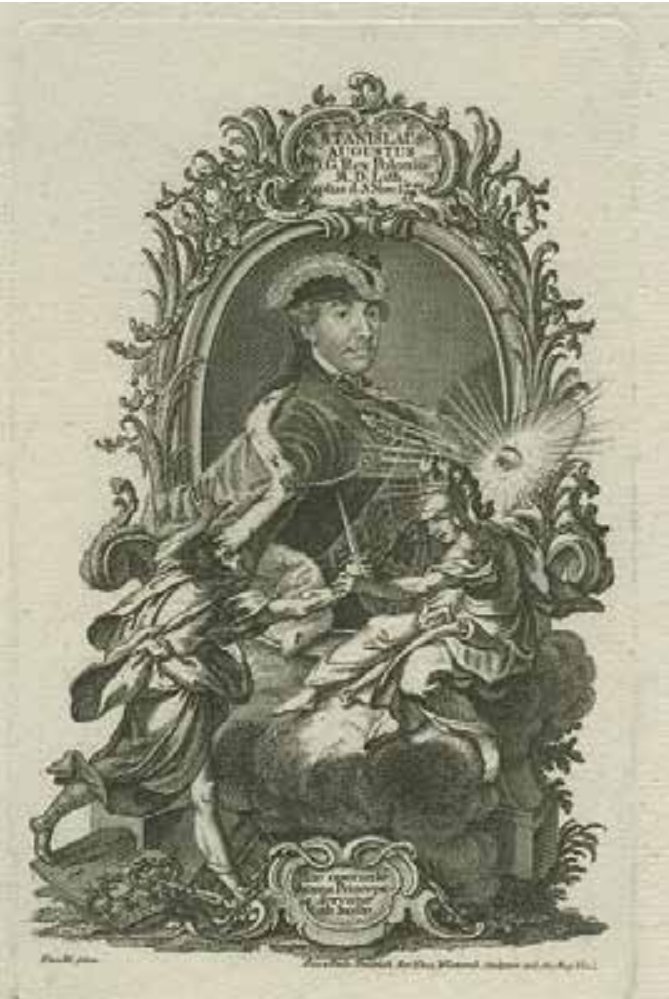

8. Jacob Andreas Fridrich Młodszy, Alegoria zamachu na Stanistawa Augusta, 1772 r. Fot. ze zbiorów autorki

Dodatkowo należy podkreślić, że ustawienie rzeźby w niszy stylizowanej na ogrodową altanę wiąze się ściśle z faktem, iż Wenus, italskie wcielenie Afrodyty, była uznawana za boginię ogrodów $w^{46}$. Posąg Wenus otaczają w Sali Stołowej malowidła ukazujące pod postacią grotesek symboliczny obraz uniwersum $\mathrm{i}$ istniejącego $\mathrm{w}$ nin porządku. Widzimy tu m.in.: alegori Czterech Kontynentów, Czterech Żywiołów, Czterech Pór Dnia, Znaki Zodiaku. W treści programu obecne są

\section{z 1795 r., inwentarz spuścizny po Stanisławie} Auguście z 1799

46 Afrodyta, s.V. W. P. Grimal, Stownik mitologii greckiej i rzymskiej, tłum. M. Bronarska, B. Górska, A. Nikliborc, J. Sachse, O. Szarska, Wroctaw - Warszawa - także odwołania do Złotego Wieku - idealnego czasu, który miał zapanować pod rządami Stanisława Augusta ${ }^{47}$. Posąg Wenus może być zatem, moim zdaniem, interpretowany wyłącznie jako posąg bogini patronującej miłości, która rządzi przedstawionymi wokół światem i natura.

Niektórzy historycy sztuki wiązali również z masonerią słynny wizerunek króla z klepsydrą, namalowany przez Marcella Bacciarellego na początku 1793 r. zwany także portretem alegorycznym Stanisława Augusta ${ }^{48}$ (il. 5). Jest to prywatny konterfekt whadcy, ukazujący go w osony k bistym apartan i siedzącego przy stoliku, na którym leży korona z wstawioną w nią klepsydrą. Monarcha zwraca się ku oknu, za którym słońce przebija się przez ciemne chmury. $\mathrm{W}$ tle przedstawiono globus przysłonięty purpurową kotarą.

Badacze kilkakrotnie uznawali, że otaczające króla na tym portrecie atrybuty to symbole masońskie, wizerunek zaś mia to sy má wolnomia bris - rozpraszana ciemnosiobskurenebris - rozpraszania cienności obskuran mu iwstecznictwa . Owe trescimiał przywoływać widok za oknem. Na tej podstawie uważano, że symbolika masońs stała się bardzo ważna dla Stanisława Augusta pod koniec jego życia. Nie udało sie jednak odnaleźć źródeł, które potwierdzityby podobne supozycje. $\mathrm{Z}$ moich ustalen

47 A. Bernatowicz, Niepodobne do rzeczywistości. Malowana groteska w rezydencjach Warszawy
i Mazowsza 1777-1820, Warszawa 2006, s. 93, 100-108

48 A. Skrodzka, Wizerunek króla nieszczęśliwego - portret Stanisława Augusta z klepsydra, ,Biulety Historii Sztuki" 2007, r. 69, nr 3-4, s. 203-247 (tan wczéśniejszza literatura); K.Z. [K. Załęski], Portret August ostatni Udręki..., dz. cyt., s. $321-329$.

49 Zob. przyp. 2 niniejszego artykułu. W katalogu z wystawy Masoneria. Pro publico bono T. Cegiels przywołuje ów obraz, ale bez uwzględnienia najnowszych ustaleń. T. Cegielski, Masoneria..., d. wynika, że namalowany po fiasku reform zapoczątkowanych przez Konstytucję 3 maja wizerunek, jest portretem człowieka pograzizo w rozpaczy, szukającego ratunku w boskiej tunku woskiej interw sy jest to także obraz zapowiadający abdykację króla, na co wskazuje leżąca na stole korona ${ }^{51}$. Atrybuty uznawane za masońskie mają inne przesłanie ideowe. Korona o specyficznym kształcie, o ostrych, trójkątnych porcjach nawiązuje najpewniej do cierniowego wieńca Chrystusa, co potwierdzają wypowiedzi króla wielokrotnie przyrównującego swoje panowanie do pełnej cierni drogi, a swą kosobą korony pojawią sie w wielu ksiegach sobą korony pojawiają się w wielu księgach emblematów i odnoszą się do trudów, które musi znosić panujący władca. Wstawiona w koronę klepsydra z przesypanym do połowy piaskiem oznacza najprawdopodobniej czas panowania Stanisława Augusta, stanowiący na początku 1793 r. niemal połowę życia polskiego monarchy 53. $^{33}$

$$
\text { Koronę o podobnym kształcie nosił }
$$

składających się niegdyś na wystrój tzw. Sali Salomona walacu tazienkowskim. Dzieła te, powstałe w latach 1788-1793, maja obecnie status zaginionych. Cykl składał się z sześciu scen: Poświęcenie świątyni jerozolimskiej, Ofiara Salomona, Sen Salomona, Narada z królem Hiramem, Sạd Salomona i Odwiedziny królowej Saby (il. 6). Za panowania Stanisława Augusta Sala pełniła reprezentacyjne funkcje salonu, w którym przyjmowano gości. Jej program ideowy do dziś nie doczekał się przekonującej interpretacji. Wydaje się, że każde z malowideł mogło mieć alegoryczne znaczenie, a cały cykl układał się w konkretny przekaz związany z bieżącymi wydarzeniami politycznymi

\section{rodzka, Wizerunek..., dz. cyt, s. 236-237.} 51 Tamże, s. 226-228.

52 Tamze, s. 228-232. 
i rolą w nich Stanisława Augusta (Sejm Wielki i uchwalenie Konstytucji) s4. $^{54}$

Wiadomo bowiem, że ołówny bohater tych obrazów, biblijny król Izraela miał na nich rysy polskiego króla. Pojawienie się w tyc scenach Salomona sprawiło, że cykl połączono z symboliką masońskąas.

Sądzę, że wybór Salomona na głównego bohatera tych malowideł wynikał zapewne w pierwszym rzędzie z przypisywanej m mądrości, której skutkiem były rządy sprawiedliwe i pokojowe. Imię Salomon, po hebrajsku Szlomo (Shlomoh), pochodzi zresztą od słowa szalom (shalom) czyli „pokój”, ,pomyślność”, , szczęście”. W religiach żydowskiej i chrześcijańskiej jest to jedno ze świętych imion Mesjasza, zwanego Księciem Pokoju (Iz 9, 5). A, jak wcześniej wspomnian Stanisław August - jako pomazaniec Boży często i chętnie z Chrystusem się porównywał. Salomon był notabene starotestamentalnym typem Zbawiciela ${ }^{56}$. Ów wybór był także podyktowany porównaniem, na jakie chciał w tym czasie zasłużyć każdy władca

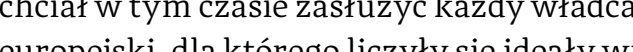
ku Rozumu - wieku Mądrości. Stanisław kugozumu - wieku już od początku swego panowania August już od początku swego panowania
był porównywany do Salomona, nazywano

\section{Ostrożną próbę odczytania niektórych z wymienio-} nych przedstawień podjełam w artykule: Virtutis invidia comes, czyli o Rotundzie w Łazienkach Królewskich, „Biuletyn Historii Sztuki” 2009, r. 71 , nr 1-2, s. 103, przyp. 46.

55 S. Dunin-Karwicki, Pałac Eazienkowski w Warszawie, Lwów 1930, s. 46-48; A. Chyczewskka, Marcello Bacciarelli 1731-1818, Wroctaw 97-98; P. Witt, Króla, I. Polaczek, Nowy Salomon, nowa „Świątynia". Watki wolnomularskie w sztuce polskiej epoki Stanistawa Augusta, „Nowa Okolica Poetów” 1999, nr 2, s. 171-172, M. Kwiatkowski, Wielka ksiega Eazienek, Warszawa . Księga ku czci prof. Andrzeja Rottermunda w 60. rocznicę urodzin od przyjaciót, kolegów i wspótpracowników, red. J. Chrościcki, Warszawa 2001, s. 357; T.Cegielski, Domek Biaty..., dz. cyt., s. 73. 56 J.L. Mc Kenzie, Dictionary of the Bible, London 1985, go również królem-filozofem. $Z$ tego też względu, jak słusznie zauważył Jakub Pokora, w przypadku dzieł związanych ze Stanisławem Augustem trudno przeko ze Stanisłá wich wskazac w nich tresci masonskie, nie myląc racjonalistyczną myślą oświeceniową̧
Jeszcze jednym „masońskim" dziełem st przedostatni portret króla namalow ny ad vivum przez Elisabeth Vigée-Lebrun w 1797 r. w Petersburgu, przedstawiający monarchę w stroju à la Henryk IV, z zawieszonym na szyi medalem na łańcuchu (il. 7$)^{58}$. Numizmat ten jest ozdobiony trójkątem na tle promieni z hebrajskim tetragramo (JHVH czyl Jehova). Prz sięre Im Boże HVH czyl Jehovah). Przebranie króla miao stanowic przede wszystkim świadectwo estymy, jaką Stanisław August darzył Henryka IV Burbona zwanego Wielkim, uznawanego za wzór władcy oświeceniowego ${ }^{59}$. Medal, który Stanisław August ma na szyi, faktycznie przypomina niektóre rzeczywiste odznaki lóż ${ }^{60}$. Wyobrażenie to jest także identyczne z tarczą wieńcząca yykonany przez Jana Griesmayera sylw wow wy portret Teresy Tyszkiewiczowej $w$ otoczeniu symboli farmazońskich ${ }^{61} . Z$ tego względu zwolennicy masońskich interpretacji stanisławowskich dzieł sztuki z upodobaniem przywoływali rzeczony obraz na potwierdzenie swoich racji. Zauważmy jednak, źe konterfekt Vigée-Lebrun powsta

57 J. Pokora, Stanistawowi Augustowi panegiryk intarsja pisany (drzwi w torunskim ratuszu), „Rocznik Histo

58 A. Skrodzka, Wizerunek..., dz. cyt., s. 237; taż, Udręki. dz. cyt., s. 344-348. O tym portrecie ostatnio onografia Stanisława Augusta. Portrety, w:

Stanistaw August, ostatni..., dz. cyt., s. 149-151.

59 J. Pokora, Obraz Najiaśnieiszego Pana Stanisława Augusta (1764-1770). Studium z ikonografii władzy, Warszawa 1993, s. 39.

60 P. Witt, dz. cyt., s. 41, 44; K. Załęski, Polski.., dz. cyt. 61 P. Witt, dz. cyt., s. 41, 44; K. Załęski,Polski..., dz. cyt. na wygnaniu, w oddaleniu Stanisława Augusta od ojczyzny, w sytuacji zależnośc finansowej i politycznej króla od carów rosyjskich. W takich warunkach z pewnoś propagowanie treści farmazońskich nie było kluczowe dla polskiego monarchy. Najistotniejsze wydaje się tutaj wyeksponowanie medalionu z boskim Imieniem w trójkącie, który to znak w sztuce stanow symbol Opatrzności $i^{62}$. Jego przedstawienie znajdziemy w XVIII-wiecznych wydaniach podręczników ikonologicznych, na czele z dziełem Cesarego Ripy, gdzie promieniejace słońce z wpisanym weń trójkatem z tecragramen

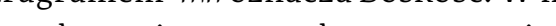
przekonaniu, monarcha na portrecie Vigé Lebrun podkreślat rolę Opatrzności we własnym życiu. Wiszący na jego piersi medalion być może nawiązuje do atrybutu personifikacji Mądrości i jako taki jest symbolem mędrca oświeconego Bożym światłem. Potwierdza to tradycja ikonograficzna.

W XVIII-wiecznym wydaniu podręcznika

Ripy widzimy alegorie Sapientiae pod posta-

Ripy widzzy a post cią kobiety depczą jegalia, zwróconej ku silnemu snopowi światła padającego z nieb zasnutego ciemnymi chmurami. Na piers
niewiasty widnieje medalion solarny $y^{6}$.

Odrzucając masońskie interpretacje wymienionych dzieł sztuki, należy przedstawić jeszcze następujące argumenty. Przywołane artefakty wykorzystuja wprawdzie symbole używane w mitologii i rytualistyce masońskiej, ale nie należy zapominać, że owe znaki zostały przejęte przez ikonosferę wolnomularską z ikonoprzez ikonosferę wolnomularską z ikono-

grafii chrześcijanskiej oraz świeckiej. W sztuce stanisławowskiej symbol Bożej
Opatrzności pojawia się często, ponieważ,

62 C. Moisan-Jablonski, Symbolika obrazu „Alegorii Boże Opatrzności" z klasztoru sióstr wizytek w Krakow
saeculum Christianum" $2015, \mathrm{t}$. 22, s. 172-183.

3 C. Ripa, Baroque and Rococo Pictorial Imagery. The 1758-60 Hertel Edition of Ripa's Iconologia with 200 Engraved Illustrations, red. E.A. Maser, New York 19 jak wspomniano wyżej, król uważał, że Providentia Divina opiekowała się nim przez całe jego panowanie ${ }^{64}$. Wạtek Opatrzności obecny jest wikonografii królews medalach i żetonach koronacyinych z lemmedalach iżetonach koronacyjnych z IP HANC IUSSIT FORTUNA MERER [Przeznaczenie kazało na nią [koronę] zasłużyć]. Wierzono powszechnie, że to za sprawą Przeznaczenia, utożsamianego z chrześcijańską Bożą Opatrznością, Stanisławow Antoniemu Poniatowskiemu przypadł w udziale tron polski ${ }^{65}$. Opatrzność zaś dla króla była Bogiem osobowym, w rozumieniu przyjętym w religii rzymskokatolickiej66. Byt On dla niego Stwóra, ktorywadzi losy tak tudzkosi, aki i knory prowadzi losy takk luk sosi, jaki jednostek, sprawując opiekę nad swymi wybrańcami67. Z zachowanych relacji wiadomo, że kontakt Stanisława Augusta z Absolutem nie ograniczał się jedynie do zewnętrznej religijności. Monarcha posiadał głębsze pragnienia duchowe wyrażane w potrzebie modlitwy ${ }^{68}$. Kierował do Boga prośby, żalił się na swój los i dziękował Mu za pomoc ${ }^{69}$.

Wątek prowidencjalistyczny jeszcze kilkakrotnie pojawił się w ikonografii stanisławowskiej ${ }^{\circ}$. Obecny był zwłaszcza w dziełach sztuki związanych z porwaniem i „cudownym" uratowaniem króla feralnej

4 A. Zamoyski, Ostatni król Polski, ttum. E. Horodyska, oprac. A. Zgorzelska, Warszawa 1994, s. 192.

65 J. Pokora, Obraz..., dz. cyt., s. 44-45.

66 O Opatrzności zob. Z. Krzyszowski, P. Moskal, Z. Pałubska, S. Brzozecki, Opatrznośc Boża, w: Encyklopedia katolicka, t. 14, red. S. Wilk, Lublin 2010, szp.

67 Nie ma zatem chyba racii Adam Zamoyski twierdząc, że „stanistaw August był w większym stopn
niż katolikiem”. A. Zamoyski, dz. cyt.. s. 137.

68 J. Michalski, Stanistaw August Poniatowski, Warszawa 2009, s. 101.

moyski, dz. cyt., s. 184-185.

70 A. Skrodzka, Stanistaw August - rex infelix. Ikonografia z okresu panowania, w: Stanistaw Augusti jego Materiały z wykładów, red. A. Sołtys, Z. Zielińnska, Warszawa 2013 (Zamek Krolewski w Warszawie. 
nocy z 3 na 4 listopada 1771 r. Stanisław August i jego otoczenie byli przekonani, że to właśnie Providentia w niezwylkły sposób ocaliła go wówczas z opresji.

Świadectwem tego przekonania są choćby następujące dzieła sztuki: rycina Franza Rolffsena upamiętniająca ustanowienie święta ku czci Bożej Opatrzności, sztych Jacoba Fridricha Młodszego Alegoria zamachu na Stanisława Augusta (il. 8), zaginiony medalion André Le Bruna Alegoria opieki nad Stanisławem Augustem, medal Johanna Leonharda Oexleina Nolite tangere christos meos, czy obraz Posłuchanie młynarza Marcella Bacciarellego, wszystkie datowaMarcella Bacciare ne po 1771 r. Do grupy obiektów związanych z wiarą króla w to, ze jego życiem ruje Boża Opatrznośc, należy zatem zaliczyć także, moim zdaniem, projekty kościoła ujazdowskiego oraz wspomniany portret króla pędzla Vigée-Lebrun.

Wobec powyższych ustaleń musimy stwierdzić, że nie mamy dziś żadnych dowodów, które w sposób przekonujacy pozwalałyby na dopatrywanie się w omówiozwal nych dziehach sztuki tresci masonskich. Argument o przynależnosci Stanisława Augusta do "konfraterni" jest niewystarczającym, w mojej ocenie, aby widzie w tych obiektach przekaz wolnomularski. Co do obecności Stanisława Augusta w kręgach wolnomularskich za najbardziej przekonujące uważam opublikowane dziesięć lat temu ustalenia historyka Jerzego . stanislawowsk wr. przez profesora badań wynika, że królmasonerię traktowa z dystansem inie podchodził poważnie do związanych z nią wierzeń i obrzędów. Michalski przyznaje, że rzeczywiście, Stanisław August wstapił do farmazonii, ale wyłącznie po to, by miec wpływ na jej członków. W ten sposób chcia

11. Skrodzka Udręeri dz cyt, s. 284-310.

72 J. Michalski, dz. cyt., s. 101. kontrolować to, co się działo w warszawskiej gałęzi ruchu. Monarsze udało się dzięin swoich przeciw płynąc przez bliskich wspólpracowników a reorganizację loż . Innym celem władcy było zapewne zdobycie sympatyków wśród "braci". Na podstawie wniosków Michalskiego uczestnictwo Stanisława Augusta w działalności tejże organizacji jawi się jako pasywne i wolno przypuszczać, że dla króla nie było na tyle atrakcyjne, by zaistniéc w zamawianych przez niego dzietach z tego wzgleqdu dopatrywa ge pę tresci masońskich w sztuce zamawiane przez Stanishwa Augusta na tę chwilę jaw ię jako nadinterpretacja.

\section{MASONIC TOPICS IN THE ART \\ AT THE COURT OF STANISLAUS}

AUGUSTUS

AGNIESZKA SKRODZKA

During the reign of Stanislaus Augustus many Polish luminaries of art and culture, and numerous politicians and statesmen belonged to the freemasonry order. In 18th entury Europe this organisation was gainng more and more members, including individuals from royalty. It has been presumed that King Stanislaus Augustus was also a member. Art historians have tried to uncover hidden messages in the artwork commissioned by the king in the search for uncover masonic motives. This article is an attempt to refute such interpretations. The author would conferm she validity of such would confirm the validity of such interpretations.
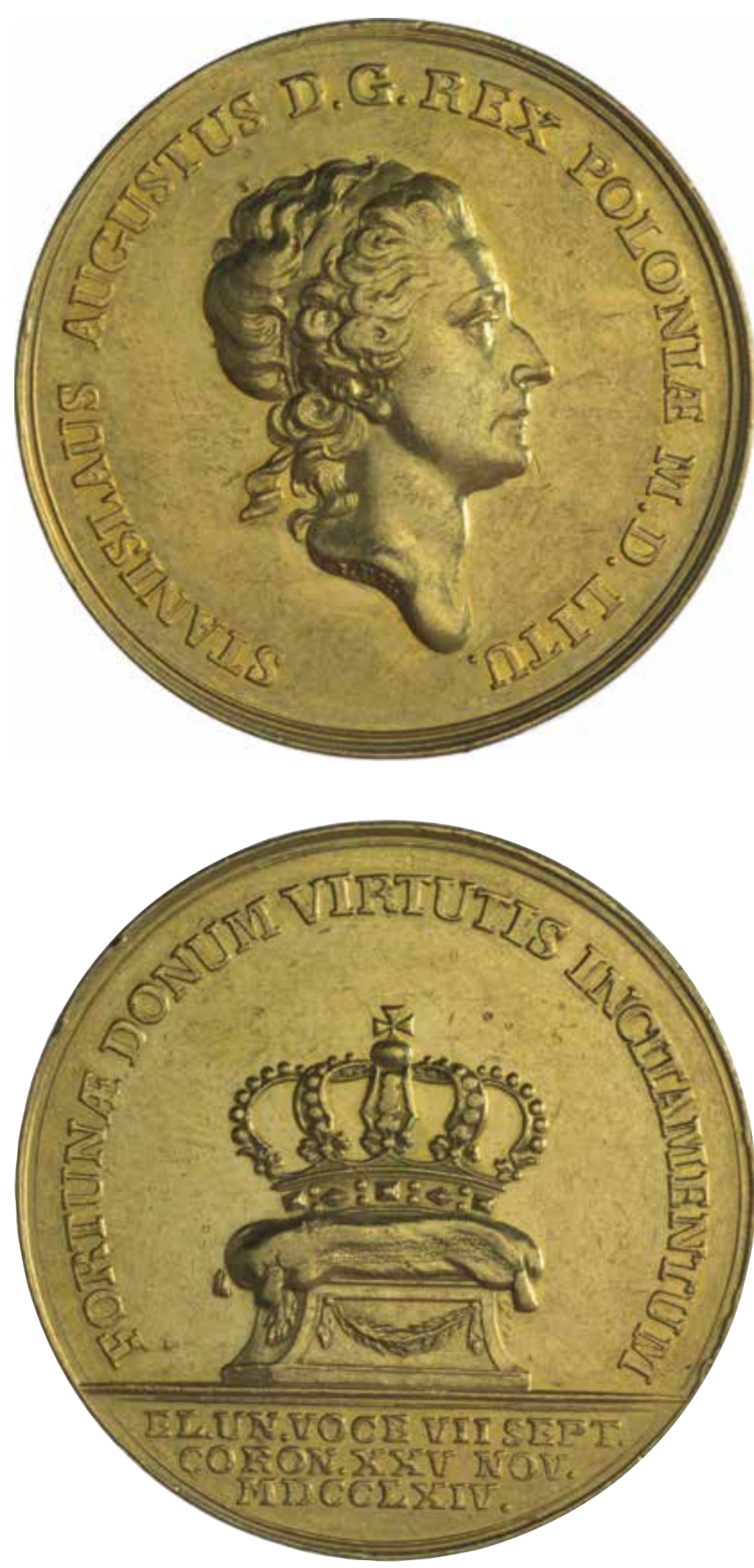